Journal

of Geography,

Politics and Society

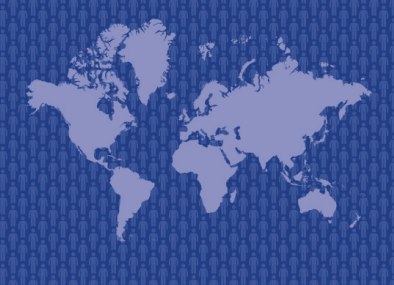

$10(1) / 2020$

\section{Journal of Geography, Politics and Society}

$2020,10(1), 15-22$

https://doi.org/10.26881/jpgs.2020.1.03

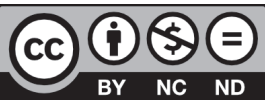

\title{
INFORMATION AND COMMUNICATION TECHNOLOGY (ICT) AS A SOURCE OF DEVELOPMENT OF STATES AND REGIONS IN THE AGE OF GLOBALIZATION
}

\author{
Agnieszka Bógdał-Brzezińska \\ Faculty of Political Science and International Studies, University of Warsaw, Krakowskie Przedmieście 26/28, 00-927 Warsaw, Poland, ORCID: 0000-0003-0247-1941 \\ e-mail: bogdal@uw.edu.pl
}

\section{Citation}

Bógdał-Brzezińska A., 2020, Information and Communication Technology (ICT) as a source of development of states and regions in the age of globalization, Journal of Geography, Politics and Society, 10(1), 15-22.

\begin{abstract}
The article presents the current evolution of the global information society and the problem of digital divide. An additional category is globalization, which has been presented as an accelerator for the development of a global information society. The role of ICT in filling the development gap between regions of the world was identified on the basis of the UN classification. The concept of "digital divide" was introduced as a synonym for a new kind of development gap between the rich North and the poor South, and analysis of data from UN publications showed a constant high diversity of the global information society, which is clearly regionalized.
\end{abstract}

\section{Key words}

global information society, globalization, digital divide, development, information and communications technologies.

\section{Introduction: Globalization and Global Information Society}

For nearly a quarter of a century we have been observing the development of a new social formation called the global information society (GSI). It is a product of changes taking place all over the world under the influence of technological development, especially in the field of computerization and telecommunications. Becoming ubiquitous in everyday life, these areas also affect the economy and the public sphere. It plays a major role in the effective processing and use of information. Three important tools for the development of the information society: data, information and knowledge form the basis for building such new fields of science, as knowledge management, and are also resources that affect the functioning of national economies and information society (Zins, 2007). Financial and industrial capital is replaced by educated human capital, and as part of globalization, a new form of economics is developing - knowledge-based economy (KBE). Knowledge is a substitute for all factors of production, which is why, as an American researcher M. Castells rightly points out (2010, p. 150): "information is a raw material: there are technologies working on information, 
just as there are technologies for coal". Therefore, a modern enterprise faces the need to invest in knowledge and innovation as a basic production resource, while human capital becomes a fundamental investment capital.

The knowledge-based economy develops unevenly across regions and groups of countries. Developmental inequalities can be clearly seen on the example of e-commerce in individual regions. The new economy (a new form of global economy based on the wide use of ICT) was to become a panacea for the ills of global underdevelopment of the countries of the South; however, pessimistic scenarios for the development of KBE and the information society (see below) have proven themselves. In the 1990s, UN Secretary General K. Annan assessed that the emergence of e-commerce had radically changed the economic and social landscape (BógdałBrzezińska, 2005). For developing countries, the digital revolution brings unprecedented opportunities for economic growth and development. However, the use of e-commerce requires that consumers and enterprises meet the appropriate conditions: access - cheap computer infrastructure and cheap connection; know-how - an appropriate level of education and skills; trust - resulting from the security of electronic transactions.

"Globalization is a concept cited in social and economic sciences and popular journalism as often as the concept of information society. It occurs in the context of economic, social, political and cultural theories, as well as in journalism (...) Contemporary information societies are subject to all the effects of globalization, and theories of globalization remain in the field of information society theory and practice" (Doktorowicz, 2005, p. 95). The relationship between globalization and the development of the information society is noticed by all researchers interested in them, such as: A. Giddens (2010), M. Castells (2010), and Z. Bauman (2006). Most of them combine globalization with the emergence of conditions for the emancipation of society from the cultural and economic rules governing the modern era. Global processes are synchronous with the construction of the information society in the economically and politically dominant regions of the world, where the information sectors of the economy have become the most important force accelerating globalization and integration.

Globalization processes affect a number of phenomena integrally associated with the development of the information society. One can speak of a correlation between globalization and the information society, without explicitly deciding which of the tested qualities is primary. Rather, it should be assumed that at the current stage of their development, the information society stimulates and is subject to the influence of globalization processes. The following reflect this trend:

- rapid development of information and communication technologies (Heeks, 2010);

- universality of e-commerce and e-finance (Erdal, Burcu, 2014);

- global transfer of data and information via the Internet;

- increase of opinion-forming and political significance of the media (fourth power);

- uniformization of social behavior: model and lifestyle, consumption and leisure (Debarbieux, 2019);

- increasing the political role of ICT transnational corporations in the TNC (Watson, 2002; letto-Gillies, 2019);

- creation of new virtual communities, social networks (Duernecker, Vega-Redondo, 2018);

- creating new political elites - knowledge managers and specialists in the field of PR (Tomé, Figueiredo, 2015);

- strengthening the development gap between the rich North and the poor South, and as a consequence - the use of ICT as fighting tools by terrorist groups, e.g.: Al. Kaida, Daesh (Choi et al., 2018; Ranstorp, 2007).

In the face of technological changes, not only are the strongest countries tested, but also all social institutions. L.W. Zacher (2007) - a careful long-term observer of social and political changes and a GSI theoretician - emphasizes that we are dealing with metamorphosis in this field of an organizational nature. Traditional prescriptive and hierarchical industrial society with clear structures and clear levels of decision-making is transformed into an amorphous, networked and atomized society. Social practice determines the functioning of existing organizational principles on a macro scale, hitting the institutions and structures poorly adaptable to realities of the digital age. The world is becoming a growing network rather than institutionalized, and its structures are atomized. In this world, however, competition continues in the field of using progress tools technology, access to knowledge, innovation and modern technologies. This competition has a geographical dimension insofar as it takes place between territorial states which are global in nature but possess the headquarters of international enterprises and institutions or intergovernmental organizations. "Corporate capital is using the new technology to integrate global markets for finance, technology, and skilled and professional labor but becoming increasingly indifferent to unemployment, rural and urban 
blight, and racial and gender problems" (Watson, 2002, p. 34). Change in employment structures, related to knowledge as production factors, available to the emergence of new social classes, including a class called information workers, of which today, employees providing off sourcing services are a reliable example and offshoring, as well as new knowledge elites called cognitivism, among them managers of information management and scientists.

\section{Digital divide as a global question}

In the debate on the impact of ICT on international relations, a vast majority of issues are addressed: the impact of digital technologies on the economic and social development of states and changes in the sphere of international security under the influence of ICT. More recent studies and analyses aim to update an answer to the question: How do science and technology affect international affairs? (Weiss, 2015).

The article presents the relationship between changes in ICT development in individual countries and regions and the issue of international security. The relationship between the digital divide and the level of democracy in states will be omitted in this paper (cf. e.g. Min, 2010).

At the end of the 20th century the issue of universal computerization and its effects became the subject of increasingly lively international discussion. For so many months, the global problem was an effect of the year 2000 (Y2000, Y2M), which is a technical matter of changing the date from 1999 to 2000 in the configuration of computer systems based on Microsoft software (Li et al., 1999). Until the turn of the century, little attention was given to global policy in the relationship between international security and the development of ICT. Even key researchers primarily considered the relationship between ICT and economic and social development in countries (Nye, 2004).

In the early 2000s, the attention of international institutions was focused on the asymmetry of access to digital technologies. Among them, the UN and its affiliated organizations played a key role, including ITU and UNDP (Role of UNDP ..., 2001). At the end of the 1990s, actions were taken to organize the World Summit on the Information Society (WSIS), the first part of which was held in Geneva in 2003 and the second part in 2005 in Tunis.

Owing to the UN Secretary General Koffie Annan, the Geneva Summit became a forum for debate on digital divide and seeking remedies against the deepening of development inequalities between countries leading in digital technologies and countries in a state of digital underdevelopment (Bógdał-Brzezińska, 2005). The report Working Group on Internet Governance (WGIG) was an important summary of previous activities (Report of the Working..., 2005).

The then prepared analyses on the asymmetry of technological development of the "rich North" and the "poor South" became a subject of political debate at the highest level. International institutions indicated that "new information and communications technologies are driving globalization, but polarizing the world into the connected and the isolated" (Human Development Report, 1999, p. 5).

In "Declaration of Principles Building the Information Society: a global challenge in the new Millennium" (2003), the summit participants committed to: ensuring universal, equal and affordable access to ICT infrastructure and services; facilitating access to public domains and expanding knowledge of the possibilities of computer software; protecting freedom of expression and ensuring independence and a variety of mass media; recognizing the individual's right to free and full development; emphasizing women's role in creating the information society and ensuring equal access to ICT for them.

In the researchers' comments following the WSIS in Geneva (Padovani, 2004), reference was made to forecasts of J. Galtung, a researcher of international development inequalities. His visionary concepts concerned both the danger of a downfall of developing countries (failed states) as well as international terrorism and the war against terrorism (Galtung, 1969).

\section{Digital divide - a new formula for the "development gap" in the ITU measurements and activities}

\subsection{Digital divide - definition and measurement issues}

At the beginning of this century, the so-called Brandt's line divided the world into the rich North and the poor South with a new phenomenon called the "digital divide". There have also been opinions that the digital divide is a new form of dependence of developing countries on technologically advanced ones (Wade, 2002; Schopp et al., 2019).

It was emphasized that "less developed countries are poorly equipped with modern information and communication technologies, which are the driving forces of globalization, which pushes them to a further margin. The world is increasingly divided into 'connected' and 'unconnected', and the lack of access to telephones or the Internet only aggravates the 
backwardness and parochialism of those who have fallen behind. Inequalities in 'information economy' (...) are self-reproducing. Controlling knowledge and information have such an impact on economics that they may be prevented from influencing it" (Anioł, 2002, p. 119).

What is the digital divide? This is how the gap in access to information and communication technologies is measured, e.g. by the size of telephone networks connected to the Internet; the gap in ICT skills and free or cheap access to modern technologies; the gap in the use of ICT measured by the number of telephone conversations, the number of computer hosts, the number of people online, or the scale of the use of the Internet in business and politics, etc.; it is finally a gap in the impact of ICT on the functioning of societies - the importance for the economy and finances of the state, e-governance, education, and health care.

Ways of measuring the digital divide are a subject of scientific discussion (e.g. Barzilai-Nahon, 2006), and critics of measurement methods note that changing criteria and models for calculating the parameters of this phenomenon bring different results and its perception. (Sicherl, 2019). However, from the perspective of international studies, in this study, statistics selected by specialized organizations of the UN system have been selected, with the International Telecommunications Union (ITU) as the main intergovernmental institution promoting global activity to overcome the effects of the studied phenomenon. However, some analyses (May, Diga, 2015, pp. 88-89) indicate that ITU data before 2007 was selective due to the inability of the least-developed countries to provide complete information on ICT development, but still ICT Statistics managed by ITU helped illustrate the global deployment of ICT.

There are many reasons for the digital divide, but the basic weakness will certainly be the underdevelopment of telecommunication and satellite infrastructure. The average number of connections in OECD countries was 70 times higher at the beginning of the 21 st century, and 17 times higher in Latin American countries than in Africa. Some countries lack adequate technical facilities and population capital to take advantage of new technologies. In addition, one can mention: governments' containment of the processes of liberalization of the provider services market; high costs of network access; patent restrictions; duties and taxes on hardware and software further increase the cost of connecting to the internet - in African countries by up to 50\%; communication difficulties resulting from language differences - virtually all commercial and financial transactions via the Internet are in English.
In the research diagnosing the nature of the digital divide in the context of the activities of the UN and its affiliated institutions, reference was made to the theories separating the world into the center and periphery, after I. Wallerstein and J. Galtung: "The digital divide reflects the broader context of international social and economic relations: a centerperiphery order marked by American dominance" (Chen, Wellman, 2004, p. 41). However, it is worth noting that, unlike in Wallerstein and Galtung's theories, the rich North has been undertaking aid initiatives for the poor South related to the development of ICT for over fifteen years. An example is the G-8 Group (United States, Canada, France, Germany, Italy, Japan, United Kingdom and Russia) - 20\% of the global population and $80 \%$ of internet hosts. These countries are also responsible for the majority of global network traffic.

\subsection{Digital divide's evolution in the analysis of UN affiliated organizations}

For the purposes of preparations for WSIS in 2003, the affiliate organization of the UN - the International Telecommunications Union (ITU) prepared a report in which the measurement parameter was used: the "digital access indicator" provided convincing technological development data sets (World Telecommunication ..., 2003).

The Digital Access Index (DAI), which was then created, measured the general ability of residents of a country to access and use information and communication technologies, with the studied countries divided into 4 groups, traditionally called: high access group, advanced access, medium and low access (World Telecommunication ..., 2003). In the high access group, which comprised 25 countries, Sweden came first with the index of 0.85 . There were also other Nordic countries: Denmark, Iceland, Norway, Finland. Asian countries, such as South Korea, Hong Kong, Taiwan, Singapore and Japan, also ranked high. The third subgroup of leaders were highly developed countries of Western Europe, North America and the antipodes. In the advanced access group (40 countries) one could find, among others, Poland and Russia, as well as many less developed European economies, Mexico and Brazil, and a number of other Latin American countries, and finally - exotic countries, deriving their income from tourism, e.g. the Seychelles, the Bahamas, Barbados. The average access group consisted of 58 countries developing or transforming the economy. These are post-Soviet republics: Ukraine, Belarus, Kazakhstan, Armenia, Georgia, as well as small Latin American countries: Guatemala, Salvador, Paraguay, and finally - representatives of sub-Saharan Africa - Namibia, 
Botswana, as well as Arab countries: Tunisia, Oman, Libya. The last group - low access - included 55 mainly African countries, whose presence in the ranking proves that there are no countries in the world not connected to the Internet. DAl for Chad and Burkina Faso, the last in the ranking, was 0.10 and 0.08 , respectively.

The report also includes auxiliary rankings, where the asymmetry of technological development between the North and the South was even more pronounced. Among the countries most intensively using the Internet were: Iceland, Sweden, South Korea, the USA and Japan. South Korea, Hong Kong, Canada, Taiwan and Belgium, the Netherlands and Denmark turned out to be leaders due to the use of broadband connections. Users in Hong Kong, the USA, Singapore, Denmark and Canada enjoyed the highest affordability of internet connection. As calculated, between 1998 and 2002, the highest DAl development was recorded in as many as 4 Far Eastern countries (South Korea, Taiwan, Singapore, Hong Kong) and only one non-Asian - Denmark.

Along with the development of the European strategy for building the information society, the initiative to reduce distance belongs to the Union. In Central and Eastern Europe one can observe a low level of infrastructure and a large diversity between individual countries: Estonia was leading, the Czech Republic was second, and Slovenia third. Before accession to the EU, the countries participated in pilot programs: e-Europe+ which were to bring the region closer to the level of Western Europe. Asia and the Pacific region, in turn, have demographic potential, which means that 50 million Internet users arrive every year. Fast, permanent connection systems dominate in Japan, China, Korea, Hong Kong which monopolize over $45 \%$ share in global broadband connections. However, the transport of goods sold online fails. Latin America, in turn, was a polycentric region, in which 4 largest markets, Brazil, Argentina, Mexico, Chile, dominated 2/3 of the users in the region. Africa was in the most difficult position.

Currently, data from the International Telecommunications Union shows that despite the numerical growth of Internet users to 4.1 billion in 2019, the problem of development barriers remains. In 2005 , this figure was $16.8 \%$ of the world population, i.e. around 1.5 billion people, in $2007-18.4 \%$ of the population, in $2009-25.8 \%$, in $2011-31.8 \%$, $2013-37.0 \%$, in $2015-41.5 \%$, in $2017-49,0 \%$, and in $2019-53.6 \%$. (Measuring digital ..., 2019). There was a clear increase in internetization - by $5 \% \mathrm{com}$ pared to 2018. The slowdown in internetization is noticeable in those countries that have been leaders of digitization in recent years. Their economies are now experiencing market saturation with technology. Most offline populations live in the least developed countries, while on average over $87.0 \%$ of internet users live in developed countries, $47.0 \%$ in developing countries and $19.0 \%$ in the least developed countries. The division into world regions is as follows: Europe $-82.0 \%$, America - 77.0\%, Asia and the Pacific- $48.5 \%$, Africa $-28.2 \%$.

It is worth noting that compared to the research conducted for the summary of WSIS II in Tunis (Huyer et al., 2005), there are no changes towards global ICT equality. In light of the ITU data from 2019 (Measuring digital ..., 2019), depending on the level of development of regions and groups of countries, the "digital gender gap" is still visible, which is also related to the education deficit among women, as well as other cultural aspects. While in Europe $85.0 \%$ of men and $80.0 \%$ of women use the Internet, in Americas $77.0 \%$ and $76.0 \%$, in Asia-Pacific $55.0 \%$ and $41,0 \%$, in Africa $34.0 \%$ and $22.0 \%$. On a global scale, this means $58.0 \%$ of male Internet users and $48.0 \%$ of female Internet users, in developed countries $87.0 \%$ and $86.0 \%$, in developing countries $53.0 \%$ and $41.0 \%$, and in the least developed countries $24.0 \%$ and $14.0 \%$. You can see a different way of using the internet for men and women. "Compared to men, women have lower frequency of use, lower intensity of use, narrower range of online activities and lower likelihood of reporting strong internet skills" (Robinson et al., 2015, p. 572).

In recent years, ITU has been preparing reports based on statistics on the development of ICT in the world "which ranks countries based on a composite number of ICT readiness, intensity and impact" (May, Diga, 2015, p. 88). The parameter called IDI (ICT Development Index) allows the comparison of changes taking place in individual regions and countries with the average values of ICT participation in social life and the global economy (The ICT Development..., 2017).

In 2017, the average IDI value for the whole world was 5.11, while for Africa 2.64, for Americas 5.21, for Arab countries 4.84, for Asia and the Pacific 4.83, for CIS 6.05, for Europe 7.50. In the group of highly developed countries, the IDI was 7.52, in the group of developing countries 4.26, and in the group of developed countries the least 2.2 (Measuring the Information Society Report, 2017). The first five places among countries in the world in the IDI ranking for 2017 were taken by: Iceland (8.98), South Korea (8.85), Switzerland (8.74), Denmark (8.71), Great Britain (8.65). At the beginning of the 21 st century, Estonia had the highest ratio among Eastern European countries -17 th in the world (8.14), while Poland ranked 49th (6.89). 
The results of research conducted over fifteen years by non-ITU researchers show that the digital divide has fallen in relative terms, but not in absolute terms. Countries, starting from lower ICT levels, do not implement ICT faster than leaders. Continental region-wise analysis also shows that the catch-up is maximum for already developed countries, and minimum for countries in African and Oceania (Kathuria, Oh, 2018).

\subsection{Contemporary initiatives of ITU to reduce the digital divide}

Due to the increase in the qualitative differentiation of problems associated with overcoming the digital divide by groups of countries in individual regions of the world, ITU's activities in the discussed area are becoming increasingly specialized. The organization strives to coordinate national ICT policies, fill gaps in the development of knowledge-based economy sectors, and bring together regional priorities for the development of information societies. This trend has recently been reflected in the decisions of the World Telecommunication Development Conference (WTDC 17), which took place on October 9-20, 2017 in Buenos Aires. Before WTDC 17, ITU held six regional preparatory meetings (RPMs) around the world in 2016-2017: in Bishkek, Kyrgyzstan, for the Commonwealth of Independent States (CIS); in Kigali, Rwanda, for Africa; in Khartoum, Sudan, for the Arab States; in Asunción, Paraguay, for Americas; in Bali, Indonesia, for Asia and the Pacific; and in Vilnius, Lithuania, for Europe. Each regional preparatory meeting was preceded by a one-day Regional Development Forum. The regions articulated their specific priorities in 30 regional initiatives - five per region for each of the six regions (Africa, Americas, Arab States, Asia-Pacific, CIS and Europe). These regional initiatives were endorsed by WTDC-17 and are featured in the "Buenos Aires Action Plan". Regional initiatives are intended to address specific ICT priority areas, through partnerships and resource mobilization to implement projects. Under each regional initiative, projects are developed and implemented to meet the region's needs. The final report of the Conference specified the so-called regional goals of ICT development for the next years (World Telecommunication ..., 2017).

The following goals have been set for Africa: building digital economies and fostering innovation in Africa, promotion of emerging broadband technologies, building trust and security in the use of telecommunications/information and communication technology, strengthening human and institutional capacity building, management and monitoring of the radio frequency spectrum and transition to digital broadcasting. The following goals have been set for Americas: disaster risk reduction and management communications; spectrum management and transition to digital broadcasting, deployment of broadband infrastructure, especially in rural and neglected areas, and strengthening of broadband access to services and applications, accessibility and affordability for an inclusive and sustainable Americas region, development of the digital economy, smart cities and communities and the Internet of Things, promoting innovation. The following goals have been set for the Arab States: environment, climate change and emergency telecommunications, confidence and security in the use of telecommunications/information and communication technologies digital financial inclusion, Internet of Things, smart cities and big data, innovation and entrepreneurship. The following goals have been set for Asia and Pacific: addressing special needs of the least developed countries, small island developing states, including Pacific island countries, and landlocked developing countries, harnessing information and communication technologies to support the digital economy and an inclusive digital society, fostering development of infrastructure to enhance digital connectivity, enabling policy and regulatory environments, contributing to a secure and resilient environment. The following goals have been set for Commonwealth of Independent States: development of e-health to ensure healthy lives and promote well-being for all, at all ages, use of telecommunications/information and communication technology to ensure inclusive, equitable, quality and safe education, including the enhancement of women's knowledge of information and communication technologies and e-government, development and regulation of info communication infrastructure to make cities and human settlements inclusive, safe and resilient, fostering innovative solutions and partnership for the implementation of Internet of Things technologies and their interaction in telecommunication networks, including 4G, IMT 2020 and next generation networks, in the interests of sustainable development. The following goals have been set for Europe: infrastructure, broadcasting and spectrum management, a citizen centric approach to building services for national administrations, accessibility, affordability and skills development for all to ensure digital inclusion and sustainable development, enhancing trust and confidence in the use of information and communication technologies, information and communication technology centric innovation ecosystems. 


\section{Conclusions}

The processes of Internet control and the use of ICT have undergone radical diffusion in recent years. The problem of the digital divide is not the main challenge arising from the global development of digital technologies, especially as a consequence of the high specialization achieved in ICT by non-state actors.

The most recognized researchers of cyberspace and international relations diagnose that "states will remain the dominant actor on the world stage, but it will be much more crowded and more difficult to control. A much larger proportion of the population, both within and between countries, has access to information-derived power" (Nye, 2010, p. 2).

Barriers to access to cyberspace are decreasing due to the spread of cheap information and communication technologies, but the control of developing countries in terms of the activity of hackers, cybercrime groups or global corporations of the ICT industry is insufficient.

In the face of the "democratization of ICT" and the growing possibilities of using the Internet as a battlefield and computers as weapons by organized hacker groups, the threat to the international order has increased. Attacks on critical infrastructure (i.e. digitally controlled and internet-connected sectors of the economy and components of the state management agsystem) have worsened the security of countries with the most-developed ICT sector.

At the current stage of development of the information society, the same development disparities that were diagnosed in the early 21 st century remain noticeable. Despite the increase in Internet access in all regions of the world (internetization), the digital divide has not been eliminated. The possession of telephones with Internet access by an increasing number of users does not mean an improvement in the economic level in the least developed countries, including African countries. There is still a correlation between cultural factors (low level of women's scholarization) and ICT development rates in Arab countries. Optimistic forecasts for the economic growth of the least developed countries under the influence of ICT's are found in the group of countries offering tourist services, but one cannot speak yet of the global nature of the knowledge-based economy. It should be recognized that ICT deepens development differences between the rich North and the poor South, becoming a source of power diversification across the world.

\section{References}

Anioł W., 2002, Paradoksy globalizacji (Eng. Paradoxes of Globalization), Instytut Polityki Społecznej UW, Warszawa.

Barzilai-Nahon K., 2006, Gaps and Bits: Conceptualizing Measurements for Digital Divide/s, The Information Society, 22(5), 269-278. doi: 10.1080/01972240600903953

Bauman Z., 2006, Globalizacja i co z tego wynika? (Eng. Globalization: The Human Consequences), PIW, Warsaw.

Bógdał-Brzezińska A., 2005, Poszerzanie statutowych funkcji sekretarza generalnego ONZ na przykładzie koncepcji Globalnego Społeczeństwa Informacyjnego (Eng. Extending the statutory functions of the UN Secretary-General on the basis of a report from the Global Information Society), Studia Międzynarodowe / International Studies, 2(1-4), 121-134.

Castells M., 2010, Społeczeństwo sieci (Eng. Network Society), Wydawnictwo Naukowe PWN, Warszawa.

Chen W., Wellman B., 2004, The Global Digital Divide - Within And Between Countries, IT\&SOCIETY, 1(7), 39-45.

Choi K., Lee C-S., Cadigan R., 2018, Spreading Propaganda in Cyberspace: Comparing Cyber-Resource Usage of Al Qaeda and ISIS, International Journal of Cybersecurity Intelligence \& Cybercrime, 1(1), 21-39. doi: 10.13140/ RG.2.2.22401.92006

Debarbieux B., 2019, Social Imaginaries of Space: Concepts and Cases, Edward Elgar, Cheltenham.

Declaration of Principles Building the Information Society: a global challenge in the new Millennium, 2003, Document WSIS-03/GENEVA/DOC/4-E, https://www.itu.int/net/wsis/ docs/geneva/official/dop.html (accessed 5 January 2020).

Doktorowicz K., 2005, Europejski model społeczeństwa informacyjnego: polityczna strategia Unii Europejskiej w kontekście globalnych problemów wieku informacji (Eng. The European model of the information society: the political strategy of the European Union in the context of global problems of the information age), Wydawnictwo Uniwersytetu Śląskiego, Katowice.

Duernecker,G., Vega-Redondo F., 2018, Social Networks and the Process of Globalization, The Review of Economic Studies, 85(3), 1716-1751. doi: 10.1093/restud/rdx054

Erdal A., Burcu K.S., 2014, The Relationship between Globalization and E-Commerce, Procedia - Social and Behavioral Sciences, 150, 1267-1276.

Galtung J., 1969, Violence, Peace, and Peace Research, Journal of Peace Research, 6(3), 167-191.

Giddens A., 2001, Nowoczesność i tożsamość (Eng. Modernity and Self-Identity), Wydawnictwo Naukowe PWN, Warszawa.

Heeks R., 2010, Do Information and Communication Technologies (ICTs) Contribute to Development?, Journal of International Development, 22(5), 625-640. doi: 10.1002/ jid.1716

Human Development Report, 1999, UNDP, Oxford University Press, New York - Oxford.

Huyer S., Hafkin N., Ertl H., Dryburgh H., 2005, Women in the Information Society, [in:] G. Sciadis (ed.), From the Digital Divide to Digital Opportunities: Measuring Infostates for Development, Orbicom, Montreal, 135-195. 
letto-Gillies G., 2019, The Role of Transnational Corporations in the Globalisation Process, [in:] J. Michie (ed.), The Handbook of Globalisation, Edward Elgar Publ., Cheltenham, 155-164.

Kathuria V., Oh K.Y., 2018, ICT Access: Testing for Convergence Across Countries, The Information Society, 38(3), 166-182. doi: 10.1080/01972243.2018.1438549

Li F., Williams H., Bogle M., 1999, The 'Millennium Bug': its origin, potential impact and possible solutions, International Journal of Information Management, 19(1), 3-15.

May J., Diga K., 2015, Progress Towards Resolving the Measurement Link Between ICT and Poverty Reduction, [in:] A. Chib, J. May, R. Barrantes (eds.), Impact of Information Society Research in the Global South, Springer Open, Singapore - Heidelberg - New York - Dordrecht - London, 83-104. doi: 10.1007/978-981-287-381-1

Measuring digital development: Facts and figures, 2019, https://www.itu.int/en/ITU-D/Statistics/Pages/facts/default. aspx (accessed 21 November 2019).

Min S-J., 2010, From the Digital Divide to the Democratic Divide: Internet Skills, Political Interest, and the Second- Level Digital Divide in Political Internet Use, Journal of Information Technology \& Politics, 7(1), 22-35. doi: 10.1080/19331680903109402

Nye J.S., 2004, Power in the Global Information Age From realism to globalization, Routledge, London.

Nye J.S., 2010, Cyberpower, Belfer Center for Science and International Affairs, Harvard Kennedy School, Cambridge.

Padovani C., 2004, Three questions about WSIS. A civil society perspective from within, Information Technologies and International Development, 1(3-4), 123-125.

Ranstorp M., 2007, The virtual sanctuary of al-Qaeda and terrorism in an age of globalization, [in:] J. Eriksson, G. Giacomello (eds.), International Relations and Security in the Digital Age, Routledge, London, New York, 31-56.

Report of the Working Group on Internet Governance, 2005, Château de Bossey, https://www.wgig.org/docs/WGIGREPORT.pdf (accessed 28 November 2019).

Robinson L., Cotton S.R., Ono H., Quan-Haase A., Mesch G., Chen W., Schulz J., Hale T.M., Stern M. J., 2015, Digital inequalities and why they matter, Information, Communication \& Society, 18(5), 569-582, doi: 10.1080/1369118X.2015.1012532

Role of UNDP in information and communication technology for development, 2001, DP/2001/CRP.8, http://web.undp. org/execbrd/pdf/DP2001CRP8.PDF (accessed 28 November 2019).

Schopp K., Schelenz L., Heesen J., Pawelec M., 2019, Digitalization in the Global South, TATuP - Zeitschrift für Technikfolgenabschätzung in Theorie Und Praxis, 28(2), 10-51. doi:10.14512/tatup.28.2.s10

Sicherl P., 2019, Different Statistical Measures Create Different Perceptions of the Digital Divide, The Information Society, 35(3), 143-157., doi: 10.1080/01972243.2019. 1582568

The ICT Development Index (IDI): conceptual framework and methodology, 2017, https://www.itu.int/en/ITU-D/Statistics/Pages/publications/mis2017/methodology.aspx (accessed 30 November 2019).
Tomé E., Figueiredo P., 2015, Knowledge Management and Politics at the Highest Level: An Exploratory Analysis, Management Dynamics in the Knowledge Economy, 3(2), 193-212.

Wade R.H., 2002, Bridging the digital divide. New route to development or new form of dependency, Global Governance, 8(4), 443-466.

Watson H.E., 2002, Globalization as Capitalism in the Age of Electronics: Issues of Popular Power, Culture, Revolution, and Globalization from below, Latin American Perspectives, 29(6), 32-43.

Weiss Ch., 2015, How Do Science and Technology Affect International Affairs? Minerva, 53(4), 411-430. doi: 10.1007/ s11024-015-9286-1

World Telecommunication Development Conference (WTDC17). Final Report, 2017, ITU, Buenos Aires, https://www.itu. int/en/ITU-D/Conferences/WTDC/WTDC17/ Documents/ WTDC 17_final_report_en.pdf, (accessed 30 November 2019).

World Telecommunication Development Report: Access Indicators for the Information Society, 2003, International Telecommunication Union (ITU), Geneva.

Zacher L.W., 2007, Transformacje społeczeństw od informacji do wiedzy (Eng. Transformations of societies from information to knowledge), Wydawnictwo Beck, Warszawa.

Zins C., 2007, Conceptual Approaches for Defining Data, Information, and Knowledge, Journal of The American Society for Information Science and Technology, 58(4), 479-493. 